\title{
Two decades of change: Glenside Hospital population surveys 1960-80
}

\author{
DONAL F EARLY, MICHAEL NICHOLAS
}

\begin{abstract}
Results of the fifth quinquennial survey of the patients of Glenside Hospital, Bristol, when compared with five yearly surveys over the past 20 years, show that the "rundown" of the hospital continues. There is still an accumulation of long-stay patients, mainly for non-medical reasons. They remain in hospital because of the failure to provide community facilities adequate to their needs. It is suggested that local authorities will never be able to cope with them and that the NHS should be enabled to extend their hospital services into "nursing homes" in the community.
\end{abstract}

\section{Introduction}

Cooper and Early ${ }^{1}$ reviewed the 1960 population of Glenside Hospital, Bristol, "with particular reference to the need for accommodation and outside employment." A schedule of 34 items was completed on each patient who had, on the day of the survey, been continuously in hospital for three months. Information obtained from individual case notes and records of visits, by discussion and questioning nursing staff, by reference to central hospital records, and by interviewing patients whenever necessary was then processed for analysis. The Glenside Hospital population has been surveyed at five-yearly intervals since 1960, the same technique being applied on each occasion. ${ }^{2-4}$ The present survey adopted precisely the same method as previously with a slight modification to the original questionnaire by the addition of a category of "chair-bound" to the heading "mobility."

\section{Results and comparison with previous surveys:}

On 1 January 1980 there were 416 patients (205 men, 211 women) in hospital. In 20 years the hospital population had dropped from 1012 -a fall of $59 \%$ (table I).

The total number of patients (17) detained under all sections of the Mental Health Act (1959) represents $4 \%$ of the total hospital population, compared with $2 \%$ of the 1975 survey (table II).

In comparison with the 1975 survey numbers have fallen in all categories but significantly only in those who have been in hospital for over five years (table III).

\section{Glenside Hospital, Stapleton, Bristol}

DONAL F EARLY, LRCP \& SI, FRCPSYCH, consultant psychiatrist (present appointment: emeritus consultant psychiatrist, Avon Area Health Authority)

MICHAEL NICHOLAS, MB, MRCPSYCH, consultant psychiatrist
Half of the resident population is now unemployed (table IV).

One hundred and fifty-three patients $(37 \%)$ have no known relatives or friends. By comparison, in 1960201 patients had no relatives and friends, in 1964 there were 182, in 1970 there were 143, and in 1975 there were 195 (table V).

The percentage of patients requiring nursing care has increased whereas the overall number requiring such care (in parentheses in table VI) has decreased.

Comparing the present survey with that in 1975, the proportion of patients requiring continuing psychiatric hospital care has increased, but the number has changed little for them or for those requiring geriatric care (table VII).

TABLE I-Age and sex groupings

\begin{tabular}{|c|c|c|c|c|c|c|}
\hline \multirow{2}{*}{ Year } & \multicolumn{2}{|c|}{ Men } & \multicolumn{2}{|c|}{ Women } & \multicolumn{2}{|c|}{ Total } \\
\hline & $<65$ & $>65$ & $<65$ & $>65$ & $<65$ & $>65$ \\
\hline & No $(\%)$ & No (\%) & No (\%) & No (\%) & No (\%) & No $(\%)$ \\
\hline $\begin{array}{l}1960 \\
1964 \\
1970 \\
1975 \\
1980\end{array}$ & $\begin{array}{l}354(78) \\
320(74) \\
255(74) \\
156(66) \\
114(56)\end{array}$ & $\begin{array}{r}99(22) \\
114(26) \\
88(26) \\
82(35) \\
91(44)\end{array}$ & $\begin{array}{r}316(57) \\
273(53) \\
174(44) \\
102(37) \\
75(36)\end{array}$ & $\begin{array}{l}243(43) \\
241(47) \\
222(56) \\
175(63) \\
136(64)\end{array}$ & $\begin{array}{l}670(66) \\
593(63) \\
429(58) \\
258(50) \\
189(45)\end{array}$ & $\begin{array}{l}342(34) \\
355(37) \\
310(42) \\
257(50) \\
227(55)\end{array}$ \\
\hline
\end{tabular}

TABLE II-Legal status

\begin{tabular}{lccccc}
\hline & $\begin{array}{c}1960 \\
\text { No }(\%)\end{array}$ & $\begin{array}{c}1964 \\
\text { No }(\%)\end{array}$ & $\begin{array}{c}1970 \\
\text { No }(\%)\end{array}$ & $\begin{array}{c}1975 \\
\text { No }(\%)\end{array}$ & $\begin{array}{c}1980 \\
\text { No }(\%)\end{array}$ \\
\hline $\begin{array}{c}\text { Detained } \\
\text { Section } 26\end{array}$ & $52(5)$ & $53(6)$ & $41(6)$ & $9(2)$ & $12(3)$ \\
$\begin{array}{l}\text { Section 60, } \\
65,72\end{array}$ & & & & & $5(1)$ \\
\hline
\end{tabular}

TABLE III-Duration of stay in Glenside hospital

\begin{tabular}{lrrrrr}
\hline & 1960 & 1964 & 1970 & 1975 & 1980 \\
\hline$>5$ years & 737 & 672 & 500 & 365 & 279 \\
$2-5$ years & 126 & 136 & 126 & 64 & 59 \\
3 months- & 150 & 140 & 113 & 86 & 78 \\
2 years & 135 & 131 & 121 & 110 & 72 \\
\hline 3 months & 135 \\
\hline
\end{tabular}

TABLE IV-Employment of patients

\begin{tabular}{lcccccc}
\hline & $\begin{array}{c}1960 \\
(\mathrm{n}=1012)\end{array}$ & $\begin{array}{c}1964 \\
(\mathrm{n}=948)\end{array}$ & $\begin{array}{c}1970 \\
(\mathrm{n}=739)\end{array}$ & $\begin{array}{c}1975 \\
(\mathrm{n}=515)\end{array}$ & $\begin{array}{c}1980 \\
(\mathrm{n}=416)\end{array}$ \\
\hline $\begin{array}{l}\text { Working outside } \\
\text { hospital including } \\
\text { industrial therapy } \\
\text { organisation }\end{array}$ & 55 \\
$\begin{array}{l}\text { Working in hospital } \\
\text { industrial therapy } \\
\text { department }\end{array}$ & 224 & 341 & 67 & 36 & 21 & 53 \\
$\begin{array}{c}\text { Working in hospital } \\
\text { department including } \\
\begin{array}{c}\text { ward chores } \\
\text { Unemployed }\end{array}\end{array}$ & 361 & 283 & 218 & 100 & 105 \\
\hline
\end{tabular}


TABLE v-Contacts/period in hospital

\begin{tabular}{|c|c|c|c|c|c|c|}
\hline & \multicolumn{2}{|c|}{$<2$ years } & \multicolumn{2}{|c|}{$2-5$ years } & \multicolumn{2}{|c|}{$>5$ years } \\
\hline & Men & Women & Men & Women & Men & Women \\
\hline $\begin{array}{l}\text { Goes out } \\
\text { regularly }\end{array}$ & 10 & 11 & 6 & 5 & 12 & 9 \\
\hline $\begin{array}{l}\text { Goes out } \\
\text { occasionally } \\
\text { Visited }\end{array}$ & $\begin{array}{r}5 \\
12\end{array}$ & $\begin{array}{r}6 \\
22\end{array}$ & $\begin{array}{l}5 \\
9\end{array}$ & $\begin{array}{r}6 \\
16\end{array}$ & $\begin{array}{l}21 \\
34\end{array}$ & $\begin{array}{l}18 \\
44\end{array}$ \\
\hline never visited & 4 & 8 & 5 & 7 & 82 & 59 \\
\hline
\end{tabular}

TABLE VI-Nursing care required

\begin{tabular}{lccccr}
\hline & 1960 & 1964 & 1970 & 1975 & 1980 \\
\hline $\begin{array}{l}\text { Nursing care not } \\
\text { necessary }\end{array}$ & $12 \%$ & $18 \%$ & $7 \%$ & $5 \%$ & $8 \%$ \\
$\begin{array}{l}\text { Minimal nursing } \\
\text { care }\end{array}$ & $35 \%$ & $25 \%$ & $29 \%$ & $23 \%$ & $23 \%$ \\
$\begin{array}{l}\text { Routine } \\
\text { psychiatric nursing } \\
\begin{array}{l}\text { Routine geriatric } \\
\text { nursing }\end{array}\end{array}$ & $53 \%$ & $58 \%$ & $64 \%$ & $66 \%$ & $69 \%$ \\
$\begin{array}{l}\text { Special nursing } \\
\text { Total patients }\end{array}$ & $1536)$ & $(549)$ & $(472)$ & $(339)$ & $(288)$ \\
\hline
\end{tabular}

TABLE VII-Type of accommodation required

\begin{tabular}{|c|c|c|c|c|c|}
\hline & 1960 & 1964 & 1970 & 1975 & 1980 \\
\hline $\begin{array}{l}\text { Psychiatric } \\
\text { hospital care } \\
\text { Geriatric care } \\
\text { After-care } \\
\text { Supervised } \\
\text { Unsupervised }\end{array}$ & $\begin{array}{c}558(55 \%) \\
83(8 \%) \\
321(32 \%)\end{array}$ & $\begin{array}{c}562(59 \%) \\
73(8 \%) \\
259(27 \%)\end{array}$ & $\begin{array}{r}380(51 \%) \\
71(10 \%) \\
270(36 \%)\end{array}$ & $\begin{array}{c}277(54 \%) \\
46(9 \%) \\
185(36 \%)\end{array}$ & $\begin{array}{l}254(61 \%) \\
48(12 \%) \\
97(23 \%) \\
85 \\
12\end{array}$ \\
\hline $\begin{array}{l}\text { No special } \\
\text { arrangements }\end{array}$ & $50(5 \%)$ & $54(6 \%)$ & $18(2 \%)$ & $7(1 \%)$ & $17(4 \%)$ \\
\hline
\end{tabular}

TABLE VIII-Accommodation required for patients according to age

\begin{tabular}{|c|c|c|c|c|c|c|c|c|c|c|}
\hline & \multicolumn{4}{|c|}{$<65$} & \multicolumn{4}{|c|}{$>65$} & \multirow{2}{*}{\multicolumn{2}{|c|}{ Totals }} \\
\hline & \multicolumn{2}{|c|}{ Men } & \multicolumn{2}{|c|}{ Women } & \multicolumn{2}{|c|}{ Men } & \multicolumn{2}{|c|}{ Women } & & \\
\hline & 1975 & 1980 & 1975 & 1980 & 1975 & 1980 & 1975 & 1980 & 1975 & 1980 \\
\hline $\begin{array}{l}\text { Psychiatric } \\
\text { hospital } \\
\text { Geriatric care } \\
\text { Supervised }\end{array}$ & $\begin{array}{r}86 \\
0\end{array}$ & $\begin{array}{r}73 \\
2\end{array}$ & $\begin{array}{r}54 \\
0\end{array}$ & $\begin{array}{r}45 \\
2\end{array}$ & $\begin{array}{r}40 \\
8\end{array}$ & $\begin{array}{r}65 \\
5\end{array}$ & $\begin{array}{l}52 \\
10\end{array}$ & $\begin{array}{l}71 \\
39\end{array}$ & $\begin{array}{r}232 \\
18\end{array}$ & $\begin{array}{r}254 \\
48\end{array}$ \\
\hline $\begin{array}{l}\text { after-care } \\
\text { Unsupervised }\end{array}$ & 44 & 27 & 26 & 17 & 18 & 18 & 58 & 23 & 146 & 85 \\
\hline $\begin{array}{l}\text { after-care } \\
\text { Nil required }\end{array}$ & $\begin{array}{l}5 \\
2\end{array}$ & $\begin{array}{l}6 \\
6\end{array}$ & $\begin{array}{l}7 \\
4\end{array}$ & $\begin{array}{l}3 \\
8\end{array}$ & $\begin{array}{l}2 \\
0\end{array}$ & $\begin{array}{l}2 \\
1\end{array}$ & $\begin{array}{l}5 \\
1\end{array}$ & $\begin{array}{l}\mathbf{0} \\
\mathbf{2}\end{array}$ & $\begin{array}{r}19 \\
7\end{array}$ & $\begin{array}{l}11 \\
17\end{array}$ \\
\hline
\end{tabular}

The psychiatric hospital requirements indicate rising numbers of aged patients with fewer patients considered fit for discharge even to supervised after-care (table VIII).

\section{Discussion}

The hospital population has fallen by 596 in 20 years-that is, by 30 patients a year. Of the 416 patients surveyed $17(4 \%)$ are detained. Although this is a small number (it does not include those on short orders), there is a considerably higher number of women detained (7) than there was in 1975 (2). The rise in the number of detained patients may be partly accounted for by the appointment in 1975 of a consultant psychiatrist with a special interest in forensic psychiatry. This fact may also be responsible for the rise in the number of patients with a known history of criminal acts from $23(5 \%)$ in 1975 to $32(8 \%)$ in 1980.

There were only three patients ( 2 men, 1 woman) under 25 and 44 (26 men, 18 women) under 45 ( $11 \%$ of the total). The inexorable march of senility in the past 20 years is shown by the proportion of men over 65 doubling (22\% to $44 \%$ ) and of women (over 65 ) rising from $43 \%$ to $64 \%$. The numbers of men under 65 have fallen $68 \%$ in 20 years, while the numbers of women under 75 have fallen $76 \%$ in the same period, but there is still a sizable proportion of each sex over the age of 75, 83 women $(39 \%)$ and 32 men $(16 \%)-28 \%$ overall.

The number of patients in the over-five years group fell by $86(25 \%)$, but this is still a large number. The numbers in the two to five years (59) and in the three months to two years categories (78) have shown little change since 1975. In this latter group 45 were over 65 . The numbers in the various diagnostic categories were: senile dementia (or other organic brain disease) (38), schizophrenia (22), other psychoses (12), non-psychotic disorders (5), and mental retardation (1).

In the two to five years group 35 of the 59 patients were over 65. Their diagnostic categories were: senile dementia (or other organic brain disease) (21), schizophrenia (20), affective psychoses (9), personality disorders (6), and other psychoses (3). Dementia has thus outstripped schizophrenia in the three months to five years category (59:42).

The number of patients who have been in hospital for three months or less has decreased considerably. After a gradual slight fall each quinquennium since 1960, the fall during the years $1975-80$ represents a $35 \%$ decline.

\section{EMPLOYMENT OF PATIENTS}

In addition to the $50 \%$ unemployed patients $25 \%$ are described as "working in hospital departments including ward chores"-a euphemism that indicates inactivity. The rising number of unemployed indicates advancing years. Industrial therapy within and without the hospital still makes an important contribution to the treatment of patients but the "rehabilitation honeymoon" 5 for hospital inpatients is over, and the continuation of economically viable industrial therapy in hospital will increasingly depend on the attendance of day patients."

\section{FRIENDLESSNESS}

The level of friendlessness continues to cause concern and the longer the stay in hospital the greater the isolation. Of the 279 patients in hospital five years or more, more than half are rarely, if ever, visited and have no known relatives or friends. This phenomenon is probably related to the fact that 245 patients are unmarried (59\%), social participation is considered to be poor in $187(44 \%)$, and 176 patients $(42 \%)$ show moderate to severe antisocial behaviour.

\section{NURSING CARE REQUIRED}

Of 72 patients with senile dementia and organic brain disorders, only 32 are fully mobile, 27 require routine psychiatric nursing, 22 geriatric care, and nine special care.

Guidelines for collaboration between geriatric physicians and psychiatrists in the care of the elderly agreed by the Standing Joint Committee of the British Geriatric Society and the Royal College of Psychiatrists ${ }^{7}$ suggest that non-mobile geriatric patients should be the responsibility of the geriatric service and the Nodder Report" recommends that "a high priority ... should be to provide facilities other than in mental illness hospitals for the care of patients suffering from dementia." It is evident, therefore, that between $\mathbf{4 0}$ and $\mathbf{4 5}$ of these patients would be better placed with the geriatric services. The problem of the aging schizophrenic contributes little to this problem: of 253 patients with this diagnosis, only 13 require special geriatric care. Their problem is gerontological rather than geriatric. In a survey of misplacement of the elderly in hospitals and residential homes in Leicestershire Dodd $e t a{ }^{9}$ concluded that half of the patients whom they surveyed who occupied NHS beds, required and were considered eligible for a place in a residential home and that there was little difference in the 
views of staff in acute geriatric and psychiatric specialties in this regard.

The demands of the demented, non-mobile patient require more nurses, the psychogeriatric wards being staffed to a higher ratio than the general psychiatric wards $(1: 1.5$ compared with $1: 2 \cdot 5)$. The psychiatric hospitals are probably contributing more than their share to the care of the elderly who should be cared for in geriatric hospitals. Our geriatric patients absorb a disproportionate amount of psychiatric nursing resources.

Nurses and State-enrolled-nurses with general training are capable of caring for geriatric patients. We would argue that it is a misuse of scarce psychiatrically trained nursing personnel to divert them from using their skills in rehabilitation, forensic, and other psychiatric services. Patients, therefore, remain in hospital through lack of rehabilitation facilities or in special hospitals or in prisons for want of trained staff to treat them in psychiatric hospitals.

\section{ACCOMMODATION REQUIRED}

\section{Hospital}

The numbers of patients requiring continuing psychiatric care have not varied over the past five years (277 in 1975, 254 in 1980). In Better Services for the Mentally Ill $^{10}$ DHSS quoted Mann and Cree,11 whose minimum estimate for hospital bed requirements was 17 beds per 100000 population. This figure is often quoted as the DHSS guideline. Eason and Grimes ${ }^{12}$ arrived at a figure of 33 hospital beds per 100000 population and the South-east Thames RHA $^{13}$ estimated 41 beds per 100000 population in 1983. On any of these bases, the Glenside figures are high but not disproportionately so if it is considered that the South-east Thames estimate does not allow provision for patients with special needs. And, as Hilton ${ }^{14}$ pointed out, "if these people are not in hospital they will mostly be needing full-time care elsewhere, with relatives, in hostels or in prisons or on park benches." In other words the Glenside Hospital service is caring for nearly all the "chronic" patients, the local authority having almost completely opted out. It is suggested that it may become DHSS policy to transfer responsibility for the care of the mentally handicapped from the NHS to local authorities by the sale of hospitals and by savings in running costs. We prefer the proposal made by DHSS in the care of the aged-the setting up of nursing homes within the NHS with medical, nursing, and rehabilitation staff trained and experienced in the care of psychiatric illness. ${ }^{16}$ The local authorities' track record before 1948 was of providing a sordid service for the mentally ill and the mentally handicapped, and there have been few developments since 1948 or indeed since 1959 or since 1974 which would give hope for a future in their hands.

\section{ACCOMMODATION REQUIRED ACCORDING TO AGE AND DIAGNOSIS}

\section{Senile dementia and other organic brain disorders}

Eleven patients ( 7 men, 4 women) are deemed fit to live in supervised accommodation while three men require no arrangements to be made for them or could live in unsupervised accommodation.

\section{Subnormal patients}

Forty-six men and 49 women were considered to be of subnormal intelligence. The number of those with a primary diagnosis of subnormality has fallen from $44(9 \%)$ to $19(5 \%)$. They continue to be misplaced in an adult psychiatric hospital: 12 men under 65 and four women over 65 would be more suitably dealt with in a hospital for the mentally handicapped, one man and one woman over 65 are more suitable for geriatric care, and one woman over 65 is fit for supervised after-care accommodation.

\section{Schizophrenic patients}

Fifty-three patients ( 36 men, 17 women) were considered fit for supervised after-care, while eight ( 5 men, 3 women) were deemed capable of living in unsupervised after-care accommodation.

\section{Others}

Of patients with affective illness 13 ( 3 men, 10 women) required supervised after-care and two unsupervised accommodation, while three patients with epilepsy ( 2 men, 1 woman) and nine ( 3 men, 6 women) with personality disorders required supervised conditions. One man with affective disorder, one woman with personality disorder, and two (1 man, 1 woman) with other psychoses required unsupervised accommodation.

In 1960 Cooper and Early ${ }^{1}$ considered that $31 \%$ of the hospital population required supervised or unsupervised accommodation. Today's proportion is $23 \%$ - an unacceptably high figure 20 years after the Mental Health Act (1959). The numbers are, of course, much smaller today (1012 surveyed in 1960 compared with 416 in 1980), but the increase in community-based treatment of schizophrenia represented in these figures places an increasing strain on the families of patients. The failure of local authorities to carry out their statutory responsibilities under the Act has meant that only the development of hospital-based community nursing and day services supported by the facilities of voluntary organisations has prevented a major crisis in the community. Local authorities will probably never be willing or able to fulfil their responsibilities. In this area the Avon County Social Services Committee reacted to the present financial crisis by closing its only hostel for adult psychiatric use and expended $0.7 \%$ of its $1979-80$ budget on adult psychiatric services. Nor is there any local evidence to suggest that joint funding schemes will be of benefit to adult psychiatry.

The rate of fall in the five year and more category has slowed to 17 patients a year. This figure from $1960-75$ was 25 patients a year. At the present rate of attrition, the present population in this category might disappear in 16 years. There is still a residue of patients in the two to five years group. Of the 25 men and 34 women in this category, eight men and 23 women suffered from senile or organic brain disease, leaving 17 men and 11 women who "accumulated" during the quinquennium-that is, three men and two women a year. Taken with the fall in numbers of recent admissions and the decline in the three months to two years category, it appears that the rate of accumulation is slowing down. Nevertheless, assuming a life expectancy of roughly 25 years in each case, there will be a continuing need for 125 beds for this category of patient.

\section{Conclusion}

The hospital population continues to decline but the "new chronics"1 7 are still with us. Our findings continue to confirm that retention in hospital is determined by factors other than the patients' clinical state. The Glenside surveys since 1961 have consistently shown that many inpatients do not need hospital care and that there is urgent need for local authority action on their behalf. After 20 years the matter is still urgent.

Babiker ${ }^{18}$ doubts if the definition and the provision of the necessary community support is "within the expertise and jurisdiction of psychiatrists." But the statutory authorities who have a legal responsibility to provide these services have consistently been unwilling or unable to do so and social services departments have less psychiatric expertise now than before 1974. A new service is unlikely to emerge from this source. The present workers must continue to bear the brunt.

We thank the nursing staff of Glenside Hospital, Bristol, for their help in compiling this paper and Mr Alan Hayward, principal clinical psychologist, for his help with the statistics.

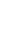
.

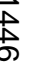

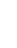
: 


\section{References}

1 Cooper AB, Early DF. Evolution in the mental hospital. Br Med $\mathcal{f} 1961$; i:1600-3.

2 Early DF, Magnus RV. Population trends in a mental hospital. Br $\mathcal{F}$ Psychiatry 1966;112:595-601.

3 Early DF, Nicholas $M$. The developing scene: ten-year review of a psychiatric hospital population. Br Med $\mathcal{F} 1971$;iv:793-5.

- Early DF, Nicholas M. Dissolution of the mental hospital: Fifteen years on. Br $\mathcal{F}$ Psychiatry 1977;130:117-22.

W Wansbrough SN. The future of industrial therapy. Lancet 1971 ; i:1009-10.

- Early DF. Twenty years of industrial therapy in Britain. International Journal of Mental Health 1978;6:80-7.

7 Arie T. Guidelines for collaboration between geriatric physicians and psychiatrists in the care of the elderly. Br $\mathcal{F}$ Psychiatry 1979;135:168-9.

8 Department of Health and Social Security. Organisational and management problems of mental illness hospitals. London: DHSS 1979. (Nodder Report.)

- Dodd K, Clarke M, Palmer RL. Misplacement of the elderly in hospitals and residential homes: a survey and follow-up. Health Trends $1980 ; 3$ : 74-6.

10 Department of Health and Social Security. Better services for the mentally ill. Command 6223. London: HMSO, 1975.

11 Mann SA, Cree W. "New" long-stay psychiatric patients. A national sample of 15 mental hospitals in England and Wales, 1972/73. Psycho Med 1976;6:603-16.

12 Eason RJ, Grimes JA. In-patient care of the mentally ill : a statistical study of future provision. Health Trends 1976;8:13-8.

13 SE Thames RHA. Strategies and guidelines for the development of services for the mentally ill. London: SETRHA, 1978. (Consultative document.)

14 Hilton J. How many places? London: National Schizophrenia Fellowship, 1979. (Discussion paper.)

15 Milmo S. MIND welcomes change. On Call 1980 Nov 20:16.

16 Stride R. NHS may set up homes for the elderly. On Call 1980 Nov 20:2.

17 Magnus R. The new chronics. Br F Psychiatry 1967;113:550-6.

18 Babiker IE. Social and clinical correlates of the "new" long-stay. Acta Psych Scand 1980;61:365-75.

(Accepted 6 February 1981)

\title{
Cancer and communication: information-giving in an oncology clinic
}

\author{
PATRICIA M REYNOLDS, R W SANSON-FISHER, A DESMOND POOLE, JENNIFER HARKER, \\ MICHAEL J BYRNE
}

Communication between doctors and patients is attracting increasing attention; yet, while patients place considerable emphasis on their doctors' ability to communicate effectively, ${ }^{1}$ most research studies show that doctors often lack the necessary skills. ${ }^{2-4}$

Communication is especially important in serious illnesses, such as cancer, which are often surrounded by myths and misconceptions. The traditional view among doctors that people with a potentially fatal illness should not be informed of that fact seems to be based on the assumption that such patients do not wish to know that they are dying. ${ }^{4-7}$ Ley's review of published reports showed that the evidence did not support that argument.4 Our investigations were designed, therefore, to find to what extent patients awaiting treatment for cancer wanted information about their illness.

Though the dominant medical attitude seems to be that patients should not be told they have a terminal illness, an alternative view is that the decision should be individually determined, on the basis of each person's intellect, emotional

Sir Charles Gairdner Hospital, Nedlands, Western Australia 6009 PATRICIA M REYNOLDS, MB, FRACP, consultant oncologist, department of medical oncology

MICHAEL J BYRNE, MB, FRACP, consultant oncologist and head of department of medical oncology

University of Western Australia, Nedlands, Western Australia 6009 R W SANSON-FISHER, MPSYCH, PHD, lecturer (behavioural science), department of psychiatry and behavioural science

A DESMOND POOLE, MSC, PHD, associate professor (behavioural science), department of psychiatry and behavioural science

JENNIFER HARKER, BA, research assistant, department of psychiatry and behavioural science state, social and cultural background, family supports, and

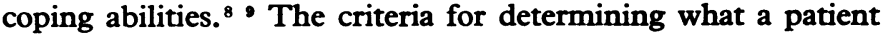
should be told, even after such a detailed assessment, are illdefined; and medical education provides little or no training to equip doctors to assess their patients in these respects. ${ }^{1011} \mathrm{Little}$ wonder, therefore, that in practice doctors tend to follow set routines in three broad categories: always avoid informing patients, always fully inform patients, or only inform those patients who specifically request information.

Each of these approaches is basically "doctor-centred." An alternative strategy is for doctors to inquire specifically what information patients want. In this way patients would be more actively concerned in the communication process. A second aim of our research was, therefore, to examine the practicality and value of adopting such a strategy as a means of determining the amount and type of information patients are given.

The final aim of the studies was to examine the effects of two techniques-explicit categorisation ${ }^{12}$ and providing patients with an audio-recording of the consultation ${ }^{13} 14$-both of which have been claimed to improve patients' recall of information.

\section{Information desired by patients}

The first study examined the nature and extent of the information patients wanted when recently diagnosed as having cancer. The sample consisted of 67 patients with cancers referred for treatment to the medical oncology clinic. During the study all new patients were contacted by a research assistant. Those who agreed to answer questions underwent a structured interview before their first appointment with the oncologist. Of the 67 patients, 56 were aware that they had been diagnosed as having cancer. Three of the remaining 11 reported being unaware of the nature of their illness, while the other eight described specific symptoms but did not appear to know the cause. 